\section{The Dyestuff Industry}

WHILST in general agreement with the admirable article on "The Dyestuffs Industry and its Lessons", in Nature of April 27, I cannot endorse your acceptance of Mr. C. J. T. Cronshaw's argument that "the industry languished because the pioneer spirit and the creative instinct which brought it into being abandoned it too early". I hold that the breakdown was entirely on the side represented by $\mathbf{M r}$. Cronshaw-the managerial and commercial side. Often in the distant past have I discussed the problem from this point of view with Griess, Caro, Dewar, Witt, Meldola, Martius and others. The commercial community is not likely to recognise this, simply because the scientific spirit is foreign to its nature.

Mr. Cronshaw attributes our downfall to the too early retirement of Perkin and others. I fear he has not the necessary feeling for the conditions prevailing in Perkin's time. History cannot be written at a distance from the events by those who have had no direct knowledge of the period considered and of the men concerned. I have more than once discussed the situation, most recently in an article in the Pharmaceutical Joumal (April 29, 1931).

Perkin's retirement meant nothing, except that he was beaten in the race. His original discovery of the dyestuff Mauve was a pure fluke. His great and real discovery was of himself-of his inborn, outstanding ability as a chemical engineer, to use the now fashionable term. He built up the industry from nothing-in particular, he transferred chemistry from glass to iron. On the other hand, he proved himself to be without imaginative power-the additions he made to the colour palette were negligible. His second advance with alizarin was inspired from Germany and was again due to his constructive ability. He worked too much in secret and failed until too late to foresee the need of a fully organised system of prospecting the field. In fact, he was himself too narrowly trained. He worked all but alone. The real advance in the industry came through E. C. Nicholson and Hofmann : through their expansion of the Rosaniline industry. In fact, the initial establishment of the dyestuff industry in England was the work of the triumvirate, Perkin, Nicholson and Hofmann. Perkin only led off. Long before Perkin retired, the fate of the industry was sealed, already in 1865, when Hofmann returned to Germany, outwearied by his attempts to create a school here. I began to study chemistry under him just before he left. Great as was the work he did, sound and broad as were the foundations he laid in aniline, our commercial outlook was too narrow and unintelligent for us to utilise his services. Our men of means and our manufacturers did not send their sons to him. His work was largely done with German assistants.

When Hofmann left the country and Nicholson retired, Perkin was left pivotless; the example they had set him was withdrawn. He made his wonderful spurt, on his second horse Alizarin, without any support from a field; soon he was left scurrying alone across the course. Nicholson had retired because his partners would not move with the times. When the firm acquired Perkin's business, it was only to prove itself unable to carry the burden. On Playfair's advice, both Griess and Dewar were approached but offered pettifogging terms. The firm took Meldola and later on Green but did not know how to use either with effect.

Our downfall was just lack of business wit: it was due to our complete failure to place ourselves upon a scientific footing. Williams, Thomas and Dower missed our third opportunity-that which Otto N. Witt gave them, of leading in the azodyestuff industry-long before Duisberg's advent. Griess and Witt, properly used together, could have established the industry here well in advance of the Germans.

We are not out of the wood to-day, Our industry is insufficiently organised on the technical side : far too narrowly commercial in its outlook. The Germans have succeeded, not through one-man management but through the close association of technical and commercial interests. The main result of our socalled rationalisation has been to eliminate technical ability and understanding to a more than dangerous extent. We are to-day, I believe, in most serious danger of again being beaten by German scientific organisation. We cannot think in high places: the commercial mind still prevails and will not brook true technical leadership. Something more than the mere association of a few academic professors with the industry is needed. In fact, the signs are only too clear that we are no longer making the progress we should : if indeed we are 'holding water'.

\section{Granville Park, Lewisham, \\ London, S.E.13.}

\section{Mutation Rates in Man}

There is at present no information concerning mutation rates in vertebrates. But where a gene produces a very great unfitness from the Darwinian point of view, that is to say, greatly diminishes the mean number of offspring produced by its bearers, then it will tend to disappear if its numbers are not kept up by mutation. The rate of disappearance is extremely slow for an autosomal recessive, very rapid for a dominant or a sex-linked recessive.

Epiloia, or tuberose sclerosis, is a condition in which tumours of the skin, brain and sometimes of the heart and kidney, are liable to be associated with epilepsy and mental deficiency. The mortality rate is high in severe cases, and probably most affected individuals have no children. Pedigrees of the condition show that it is an autosomal dominant. In each generation, however, a proportion of cases, which we estimate at about 25 per cent, are sporadic and are presumably due to mutation. The frequency of epiloia in south-eastern England appears to be of the order of 1 in 30,000 . This implies a mutation rate of about 1 in 120,000 per generation.

Hæmophilia is a sex-linked recessive condition. It is so fatal that the marriage rate of hæmophilies is about a quarter of the normal, and their actual fertility doubtless still lower. In other words, three quarters or more of the hæmophilic genes in males are wiped out in each generation, and must be replaced by mutation if the population is in equilibrium. A simple calculation shows that, if there were no mutation, the incidence of the disease would be decreasing at such a rate that 1,000 years ago the whole population of England would have been 